\title{
Problems and Optimization Measures for Internal Control System in Joint-Stock Commercial Banks
}

\author{
Wang Fengyan ${ }^{1, a}$ \\ ${ }^{1}$ School of Accountancy, Shan Dong Women' University, P.R.China, 250300 \\ aaprilwfy@163.com
}

Keywords: Commercial Banks, Internal Control Implementation, Risk Control Ability

\begin{abstract}
Based on current development of joint-stock commercial banks, this paper analyzes influencing factors for the internal control system in joint-stock commercial banks including the lingering impact of financial crisis, government intervention, functions of the board of supervisors in an empty shell as well as imperfect internal control culture, and puts forward optimization measures for these problems. For instance, internal control system construction shall take regional economic characteristics into account. The management responsibilities of the board of supervisors shall be specified, with its functions given to a full play. Internal control objectives shall be included into senior management annual performance appraisal and internal control objectives into enterprise culture construction. Also, administrative intervention shall be avoided. These measures can be taken to further promote internal control effect in joint-stock commercial banks.
\end{abstract}

\section{Introduction}

12 national joint-stock commercial banks have been set up in China since 1986, including China Citic Bank, China Everbright Bank, China Merchants Bank, China Minsheng Bank, Hua Xia Bank, Shenzhen Development Bank, Guangdong Development Bank, Shanghai Pudong Development Bank, Industrial Bank, Evergrowing Bank, China Bohai Bank and China Zheshang Bank (statistics from China Banking Regulatory Commission, 2012). In recent years, joint-stock commercial banks have expanded scale of business and made admirable achievements during the process of internationalization. For example, in March 2008, China Minsheng Bank became a shareholder of UCBH Holdings Inc. In May 2008, China Merchants Bank purchased HK Wing Lung Bank. In 2009 China Citic Bank purchased CITIC International Financial Holdings. With deepened financial openness, joint-stock commercial banks have strengthened cooperation with international financial institutions and worked better with the international financial market. In the meantime, faced with the fierce market competition, commercial banks are also confronted with severe tests in policy adjustment in both international and domestic financial markets. Constantly expanding capital scale and innovated business scope have also brought difficulties to financial regulation and risk control.

In order to cope with market competition, joint-stock commercial banks have to expand their business scale, but their risk control ability has failed such rapid expansion. In recent years, joint-stock commercial banks have witnessed frequent internal control risk events. This reveals that some joint-stock commercial banks suffer from fast expansion, unsatisfactory branch management, insufficient risk control ability, as well as internal risk control and management that can not adapt to environmental changes.

\section{Problems for Implementation of Internal Control in Joint-Stock Commercial Banks}

Based on research analysis, we believe that joint-stock commercial banks are challenged with problems in the implementation of internal control mainly in the following aspects.

\subsection{Lingering Impact of Financial Crisis}

In the time of post financial crisis, with continuous adjustment in national macroeconomic policy, banking supervision authorities have strengthened supervision and management over the banking 
sector. On the general, the financial environment is showing a favorable development trend. The financial market is recovering to a normal state, and financial institutions are also making steady improvement in management efficiency and asset quality. Along with the rapid economic development in recent years, joint-stock commercial banks have entered soaring expansion too. The swelling capitalization and loan scale have put internal control system construction under great challenges. In this economic background, some institutions have experienced risks in liquidity and internal control due to imperfect internal control mechanism, which is caused by weak risk control ability, insufficient liquidity risk prevention as well as risk control and management that fail to adapt to environmental changes.

\subsection{Government Intervention}

Since most major shareholders of joint-stock commercial banks are state shares (e.g. the biggest shareholder of Industrial Bank is Fujian Provincial Department of Finance with a stake of 21.03\%. Te biggest shareholder of Bank of Communications is the Ministry of Finance with a stake of 26.52\% according to 2011 report), joint-stock commercial banks were mostly state-owned banks. Protection and management from the local government, serious administrative intervention and short time in joint-stock restructuring jointly result in poor sensitivity to market risks, thus the weak ability to identify and cope with internal control risks.

\subsection{Formalistic Functions of the Board of Supervisors}

Researches have found that the board of supervisors in certain joint-stock commercial banks is simply formalistic. There are even commercial banks that have no board of supervisors, so it is impossible to supervise and evaluate the board of directors and senior management. In some joint-stock commercial banks, there is no management policy for the board of supervisors, or major shareholders serve as members of the board, which makes the board of supervisors an empty shell. Besides, to whom shall internal auditors report and what reporting channel shall be adopted are not specified.

\subsection{Imperfect Internal Control Culture}

Compared with developed countries, the construction and development of internal control system in joint-stock commercial banks have a late start. Due to the short operating time of joint-stock commercial banks, there has not been a sound internal control culture. In China, it has been long after joint-stock commercial bank restructuring, so internal control system has not been established in certain institutions. Working staff at grassroots organizations, in particular, haven't fully realized the importance of internal control culture, and the internal control system doesn't go with enterprise business and strategic objectives. This goes against with "information communication" and "control environment" among the five elements of the internal control theory framework. As a result, admirable internal control effect can never be achieved.

\section{Optimization Measures for Internal Control System in Joint-Stock Commercial Banks}

\subsection{Internal control system construction shall take regional economic characteristics into account}

The establishment and effective implementation of internal control system requires a process. System construction cannot simply copy previous model but must take into account the characteristics of regional economic development so as to build a regional economic characterized internal control environment. Blind copying could only make it work backfire. In recent years, local governments have issued a series of regulatory documents to remind and urge commercial banks to improve their ability to analyze, warn and prevent financial risk and attach importance to financial risk monitoring, early warning and emergency response. In view of current regional environment and economic environment, commercial banks are supposed to take effective internal control measures 
and implement standardized practice, which would be an effective way to improve and optimize the internal control system in joint-stock commercial banks.

\subsection{Management responsibilities of the board of supervisors shall be specified, with full play given to board functions}

As a body for supervision and balancing in governance of joint-stock commercial banks, the board of supervisors shall be responsible for supervision and evaluation of the board of directors, senior management and its members and play an important part in financial processing, loan approval and internal control. Therefore, internal control policy shall be further strengthened to clarify the function of the board of supervisors in joint-stock commercial banks, specify internal auditing and internal supervision functions in the governance structure, define the responsibilities of the board of supervisors, examine the risk in branches and operating agencies on a regular or random basis, as well as explore and improve functions of the board of supervisors.

\subsection{Internal Control Objectives Shall Be Included Into Senior Management Annual Performance Appraisal Standards}

In the construction of internal control environment, the attitude of top management of joint-stock banks can directly reflect how the institution emphasizes the establishment and implementation of internal control system. Commercial banks shall quantify the internal control objectives, include internal control objectives into management annual appraisal, carry out point management for irregularities by the senior management, guide and supervise the conduct of the top management, minimize potential risks, or score staff on an annual basis to assess how they achieve the objective so as to prevent insider control and facilitate the effective implementation of internal control system.

\subsection{Joint-stock commercial banks shall get rid of administrative intervention and attach importance to risk assessment and management}

In order to improve market risk assessment and response ability of joint-stock commercial banks, first, local governments should impose less administrative intervention to diversify shares by reducing state-own shares and increasing shares of private capital so as to relieve commercial banks from tight regulation, lead them to market competition and improve their sensitivity to market risk.

In addition, risk assessment of business process under centralized management shall be strengthened. Under centralized management, it shall follow layered management of "decentralized acceptance at front desk, centralized processing at back stage”. When business is accepted at the counter, the bank only examines the authenticity of clients' business receipt and certificate. It is the operation center that completes accounting business and examines certificate completeness and business compliance. This operating system adopts partition management with unified operation process, which is beneficial for scale effect and can improve the efficiency of business processing.

\subsection{Internal control objectives shall become a part of enterprise culture construction}

In order to achieve internal control objectives, enterprise culture construction should give priority to the cultivation of teamwork spirit so as to spur employees to self-improvement, create, maintain and advocate an agreeable atmosphere for teamwork spirit. Moreover, joint-stock commercial banks should guide employees' values and habits and develop enterprise values. Third, joint-stock commercial banks will inevitably run into financial innovation risks in development. A powerful immune system namely the internal control system is definitely a support for such innovation risk. A good corporate culture is a helpful supplement of the internal control system, which can improve enterprise's ability to identify and prevent innovation risks.

\section{References}

[1] Guideline for Enterprise Internal Control [M]. The Ministry of Finance of the People's Republic of China, 2010. 
[2] Trial Measures for Commercial Bank Internal Control Evaluation [M]. China Banking Regulatory Commission, 2004.

[3] Guideline for Financial Institution Country Risk Management in Banking Sector [M]. China Banking Regulatory Commission, 2010

[4] Liu Kuishan. A Preliminary Study on Enterprise Culture Construction in Joint-Stock Commercial Bank [J]. Contemporary Finance, 2002 (12)

[5] Su Shibin. Problems and Countermeasures for Internal Control in State-Owned Commercial Banks [J]. Fujian Finance, 2005 (12) 